\title{
Resumption of oestrous behaviour and cyclic ovarian activity in suckling and non-suckling ewes
}

\author{
A. Schirar, Y. Cognie*, F. Louault*, N. Poulin*, M. C. Levasseur and \\ J. Martinet
}

Laboratoire de Neurobiologie de la Reproduction, INRA, 78350 Jouy-en-Josas, France; and *Station de Physiologie de la Reproduction, INRA, 37380 Nouzilly, France

\begin{abstract}
Summary. In Préalpes de Sud ewes after an autumn lambing, the mean post-partum interval to first $\mathrm{LH}$ surge was $10 \pm 1$ days and $17 \pm 1$ days for non-suckling and suckling ewes, respectively. Post-partum interval to first luteal phase, estimated from plasma progesterone concentrations, was similar in non-suckling and suckling ewes $(27 \pm 1$ days and $28 \pm 5$ days, respectively). Interval to first oestrus was shorter in nonsuckling ( $22 \pm 2$ days) than in suckling ewes $(35 \pm 2$ days) but these first oestrous periods were followed by short luteal phases in $60 \%(12 / 20)$ of non-suckling ewes and in only $7 \%(2 / 29)$ of suckling ewes. Finally, suckling slightly postponed the resumption of the first oestrus followed by a normal oestrous cycle ( $37 \pm 1$ days versus $31 \pm 2$ days) because progesterone, essential for oestrus expression, was secreted mainly during normal luteal phases in 70\% $(21 / 30)$ of suckling ewes and during short cycles in $95 \%(21 / 22)$ of non-suck ling ewes. Therefore, the primary consequence of suckling is to regulate the conditions of resumption of cyclic ovarian activity after parturition.
\end{abstract}

Keywords: ewe; post partum; breeding season; suckling; ovarian activity; oestrous activity

\section{Introduction}

In most mammals, suckling during the puerperium tends to delay the resumption of cyclic ovarian activity and the time when a new gestation becomes possible (Hammond, 1961). Under natural conditions, post-partum anoestrus in the ewe is confounded with the parturition-onset of breeding season interval (Lees, 1964; Mauléon \& Dauzier, 1965; Hunter, 1968). Induction of oestrus and pregnancy during seasonal anoestrus (Robinson, 1965; Thimonier et al., 1968) permits lambing during the breeding season and hence study of the endocrinology of the post-partum period when the effect of seasonal anoestrus is minimal. The present study is of the resumption of oestrous behaviour and ovulatory luteinizing hormone $(\mathrm{LH})$ surges, as well as the progesterone secretion by the corpora lutea formed, in suckling and non-suckling ewes.

\section{Materials and Methods}

The experiment was carried out during the breeding season in 52 multiparous Préalpes du Sud ewes (mean age 3.5 years) mated in seasonal anoestrus (end of May) after treatment with fluorogestone acetate and PMSG (Thimonier $e t$ al., 1968). In our flock this treatment permits 3 crops of lambs in a cycle of 2 years with a fertility of $85 \%$ and an overall productivity of 2 lambs per ewe. The ewes were maintained indoors in large pens under natural lighting. They were fed a mixture of hay, lucerne, pellets and cereal grain with an increased ration in the last 3 weeks of gestation and had free access to water. On Day 144 of gestation each ewe was given an injection of dexamethasone (12 $\mathrm{mg}$ ) to synchronize parturition. At $24 \mathrm{~h}$ after lambing (Day 0 ) the ewes were allocated at random to groups approximately balanced for litter size and date of parturition: one group of 30 ewes suckling 1 lamb $(\mathrm{N}=12), 2$ lambs $(\mathrm{N}=15)$ or 3 lambs $(\mathrm{N}=3$ ) (Groups S1, S2 and S3), and one group of 22 non-suckling ewes whose lambs were removed $24 \mathrm{~h}$ after 
lambing and having carried either 1 lamb $(N=13)$ or 2 lambs $(N=9)$ (Groups NS1 and NS2). The ewes were then maintained in separate pens and fed according to their respective new nutritional requirements to prevent any weight loss during the post-partum period, particularly in lactating ewes. Blood samples were collected into heparinized tubes by jugular venepuncture from all ewes once daily $(15: 00 \mathrm{~h})$ from 2 or 3 days before parturition until resumption of regular oestrous cycles in order to study progesterone secretion. However, from 21 ewes (6 in Group NS1, 6 in Group $\mathrm{Sl}, 6$ in Group S2 and 3 in Group S3) blood samples were collected every $6 \mathrm{~h}(03: 00,09: 00,15: 00$ and 21:00 h) from Day I post partum until resumption of normal oestrous cycles in order to detect preovulatory LH surges. Previous experiments carried out at our stations have shown that frequent blood sampling did not affect the behaviour of ewes and their lambs. Plasma was separated from blood samples by centrifugation and stored at $-20^{\circ} \mathrm{C}$ until assayed for $\mathrm{LH}$ and progesterone.

Oestrous behaviour was checked from parturition until the end of experiment (about Day 55 post partum) by introducing two intact apron-bearing rams twice daily to the females. During oestrus detection lambs were separated from their dams. To avoid a ram effect, rams were introduced in the sheep-fold 10 days before parturition and allowed to move between the pens for $30 \mathrm{~min}$ in the morning $(08: 00 \mathrm{~h})$ and in the afternoon $(17: 00 \mathrm{~h})$.

Radioimmunoassays. All samples from one animal were assayed in a single run. The concentration of $\mathrm{LH}$ was determined by radioimmunoassay (Pelletier et al., 1968) of duplicate quantities of plasma and results were expressed in terms of ng ovine LH M3 CNRS $(1.8 \times \mathrm{NIH}-\mathrm{LH}-\mathrm{S} 1)$ per $\mathrm{ml}$. The sensitivity of the assay was $0.3 \mathrm{ng} / \mathrm{ml}$ and the intra- and inter-assay coefficients of variation (CV) were 14,8 and $7 \%$ and 20,10 and $11 \%$ at 1,13 and $30 \mathrm{ng} / \mathrm{ml}$ respectively.

Progesterone was measured by radioimmunoassay as described by Palmer \& Jousset (1975). Detection limit of the assay was in the range of $125-250 \mathrm{pg} / \mathrm{ml}$, but the large intra-assay $\mathrm{CV}$ values in this range of concentrations led to use of only the progesterone concentrations equalling or exceeding $0.5 \mathrm{ng} / \mathrm{ml}$. Inter-assay CVs were 13 and $17 \%$ at 2 and $8 \mathrm{ng} / \mathrm{ml}$ respectively.

Analysis of data. A rise in LH was considered to be an LH surge if the value of two consecutive blood samples taken at 6-h intervals exceeded $10 \mathrm{ng} / \mathrm{ml}$. The pattern of release of $\mathrm{LH}$ and progesterone previously assessed in 13 ewes exhibiting regular oestrous activity allowed definition of the following criteria. (i) A normal ovarian cycle was a cycle with a $17 \pm 2$-day interval between two successive $\mathrm{LH}$ surges concurrent with oestrus and with progesterone concentrations of $>0.5 \mathrm{ng} / \mathrm{ml}$ for $8-15$ days. (ii) A rise in progesterone concentrations to $\geq 0.5 \mathrm{ng} / \mathrm{ml}$ for at least 2 consecutive days was considered to be a certain index of luteinization; in the absence of LH measurements, intervals between parturition and successive ovulations were derived from plasma progesterone concentrations. When progesterone concentrations were $\geq 0.5 \mathrm{ng} / \mathrm{ml}$, ovulation was estimated to have occurred 3 days before. (iii) According to whether the daily progesterone concentrations of $\geq 0.5 \mathrm{ng} / \mathrm{ml}$ were sustained for $2-7$ days, $8-15$ days or $>16$ days, the luteal phase was considered to be short, normal or long, respectively.

Statistics. All values are presented as means \pm s.e.m. Mean post-partum intervals were compared amongst groups of ewes by analysis of variance using the General Linear Models procedure with contrast statement (SAS, 1987). The percentages of abnormal luteal phases occurring in suckling and non-suckling ewes at the time of first ovulation or first oestrus were compared by $\chi^{2}$ tests used with the Yates correction.

\section{Results}

\section{First LH surge and first luteal phase}

The first LH surge occurred significantly earlier in Group NS than in Group S; the number of lambs nursed was without any significant influence (Table 1). According to our criteria, the first LH surge detected in the 21 ewes was followed by a progesterone secretion in only $57 \%$ of the ewes. Plasma progesterone concentrations did not increase after the first LH surge in any of the 6 nonsuckling ewes. In these ewes the first indication of luteinization occurred after $2.8 \mathrm{LH}$ surges on the average, at $5 \pm 1$-day intervals. However, in 12 Group $S$ ewes plasma progesterone concentrations increased by the first $\mathrm{LH}$ surge, and in the remaining 3 luteinization occurred after a second $\mathrm{LH}$ surge $6 \pm 1$ days later. The number of lambs nursed did not influence the percentage of ewes with progesterone after the first LH surge. Finally, even though the first LH surge occurred earlier in Group NS than in Group S ewes the interval from parturition to onset of first luteal phase was not different (Table 1). However, this interval was significantly shorter $(P<0.001)$ in ewes in Group S1 (19 \pm 1 days) than in those in Groups S2 and S3 (25 \pm 1 days). Conversely, this interval was similar in the ewes in Groups NS1 ( $22 \pm 2$ days) and NS2 ( $19 \pm 2$ days).

The duration of the first luteal phase was normal in $31 / 52$ ewes. In the remaining ewes luteal phases were short or long. This incidence of inadequate luteal phases was independent of the physiological status of the female (i.e. suckling or non-suckling: $\chi^{2}=2 \cdot 23 ; n=1 ; P=0 \cdot 13$ ), but 
Table 1. Resumption of oestrous and ovarian activity in ewes $(\mathrm{N})$ after parturition

\begin{tabular}{|c|c|c|c|c|c|c|}
\hline \multirow{2}{*}{$\begin{array}{l}\text { Interval from } \\
\text { parturition to: }\end{array}$} & \multirow[b]{2}{*}{ Group NS } & \multicolumn{4}{|c|}{ Group S } & \multirow{2}{*}{$\begin{array}{c}\text { Statistical } \\
\text { significance } \\
\text { (Group NS vs others) }\end{array}$} \\
\hline & & S1 & $\mathrm{S} 2$ & S3 & Total & \\
\hline First LH surge & $\begin{array}{l}10 \pm 2 \\
(5-18) \\
N=6\end{array}$ & $\begin{array}{l}16 \pm 2 \\
(10-23) \\
N=6\end{array}$ & $\begin{array}{l}18 \pm 2 \\
(14-24) \\
N=6\end{array}$ & $\begin{array}{l}16 \pm 2 \\
(13-21) \\
N=3\end{array}$ & $\begin{array}{l}17 \pm 1 \\
(10-24) \\
N=15\end{array}$ & $P<0.001$ \\
\hline First oestrus & $\begin{array}{c}22 \pm 2 \\
(9-40) \\
\mathrm{N}=20_{\ddagger}^{\ddagger}\end{array}$ & $\begin{array}{l}34 \pm 3 \\
(26-51) \\
N=11\end{array}$ & \multicolumn{2}{|c|}{$\begin{array}{l}36 \pm 2 \\
(13-45) \\
N=18\end{array}$} & $\begin{array}{l}35 \pm 2 \\
(13-51) \\
N=298\end{array}$ & $P<0.001$ \\
\hline First luteal phaset & $\begin{array}{l}21 \pm 1 \\
(10-35) \\
\mathrm{N}=22\end{array}$ & $\begin{array}{l}19 \pm 1 \\
(12-26) \\
\mathrm{N}=12\end{array}$ & \multicolumn{2}{|c|}{$\begin{array}{l}25 \pm 1 \\
(16-31) \\
N=18\end{array}$} & $\begin{array}{l}23 \pm 1 \\
(12-48) \\
\mathrm{N}=30\end{array}$ & n.s. \\
\hline First normal luteal phase & $\begin{array}{l}27 \pm 2 \\
(16-44) \\
N=19\end{array}$ & $\begin{array}{l}23 \pm 3 \\
(12-47) \\
\mathrm{N}=11\end{array}$ & \multicolumn{2}{|c|}{$\begin{array}{l}30 \pm 2 \\
(1648) \\
N=17\end{array}$} & $\begin{array}{l}28 \pm 5 \\
(12-48) \\
N=28^{*}\end{array}$ & n.s. \\
\hline $\begin{array}{l}\text { First normal oestrous } \\
\text { cycle preceded by an } \\
\text { oestrus }\end{array}$ & $\begin{array}{l}31 \pm 2 \\
(16-44) \\
N=19\end{array}$ & $\begin{array}{l}35 \pm 2 \\
(24-51) \\
N=11\end{array}$ & \multicolumn{2}{|c|}{$\begin{array}{l}39 \pm 1 \\
(26-45) \\
N=17\end{array}$} & $\begin{array}{l}37 \pm 1 \\
(24-51) \\
\mathrm{N}=28\end{array}$ & $P<0.025$ \\
\hline
\end{tabular}

Values are mean \pm s.e.m. with the range in parentheses.

tWithout prejudgement of whether it was normal, short or long in length.

$\ddagger 2$ ewes did not show oestrus within 55 days post partum.

$\$ 1$ ewe did not show oestrus within 55 days post partum.

3 ewes did not resume normal oestrous cycle within 55 days post partum.

*2 ewes did not resume normal oestrous cycle within 55 days post partum.

was related to the day of occurrence of first ovulation after parturition. When ovulation took place before Day 20 post partum the first luteal phase was normal in $38 \%$ of ewes, but when it occurred after Day 20 , the first luteal phase was normal in $74 \%$ of ewes $\left(\chi^{2}=5 \cdot 35 ; n=1 ; P=0 \cdot 02\right)$.

\section{First oestrus and first oestrus followed by a normal cycle}

All but 3 ewes ( 2 in Group NS2 and 1 in Group S1) were detected in oestrus at least once during the first 55 days after parturition. Early weaning of lambs advanced the resumption of first oestrus after lambing (Table 1). The number of lambs born did not influence this interval in Groups NS (NS1 $=25 \pm 2$ days; NS2 $=30 \pm 3$ days) or S (Table 1). These first oestrous periods were shorter than those detected later, i.e. when ewes were teased twice daily, they were in oestrus for $1.9 \pm 0.13$ checks at the first oestrous period and for $3.03 \pm 0.13$ checks at the last detected oestrus (i.e. a mean increase of $14-16 \mathrm{~h}$ in the duration of oestrus, $P<0.01$ ).

On the other hand, the frequency of abnormal luteal phases after the first oestrus was greater when oestrous periods occurred before Day 25 post partum $\left(\chi^{2}=19 \cdot 77 ; n=1 ; P<0.001\right.$, Fig. 1$)$. By taking into account the day of occurrence of the first LH surge presumably followed by a normal 17-day oestrous cycle, recurrence of oestrus should be expected on Day 27 in Group NS ewes and on Day 34 in Group S ewes. The present results showed that when oestrus resumed before these theoretical dates the frequency of subsequent abnormal luteal phases was significantly greater in Group NS than in Group S ewes (60\% versus $10 \% ; \chi^{2}=11.50 ; n=1 ; P<0.005 ;$ Fig. 1$)$.

Finally, 47 ewes out of 52 resumed normal cyclic ovarian activity within 55 days post partum ( 3 Group NS and 2 Group S ewes did not resume normal cyclicity). The first oestrus followed by a normal cycle occurred later in Group S than in Group NS ewes (Table 1). The litter size did not influence this interval ( $30 \pm 3$ days versus $32 \pm 3$ days for Group NS1 and NS2 respectively). Suckling more than one lamb did not postpone the resumption of normal oestrous cycles $(39 \pm 1$ day versus $35 \pm 2$ days; Table 1). Suckling appeared to affect mainly the expression of oestrus. At the onset of the first normal luteal phase 14/19 Group NS ewes and only 8/28 Group S ewes 


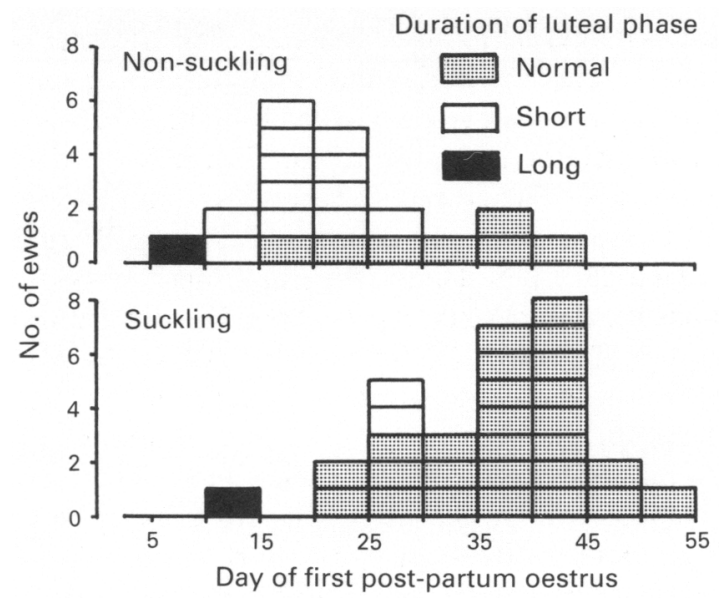

Fig. 1. Duration of the luteal phase in ewes after the first oestrus post partum.

exhibited a concurrent oestrus. In 22 Group $\mathrm{S}$ ewes the first oestrus occurred immediately after a normal luteal phase while in Group NS ewes this feature was observed only once. In these females oestrous periods occurred in the course of a series of short luteal phases ( 3 on an average) before the establishment of regular cyclic ovarian activity (Fig. 2).
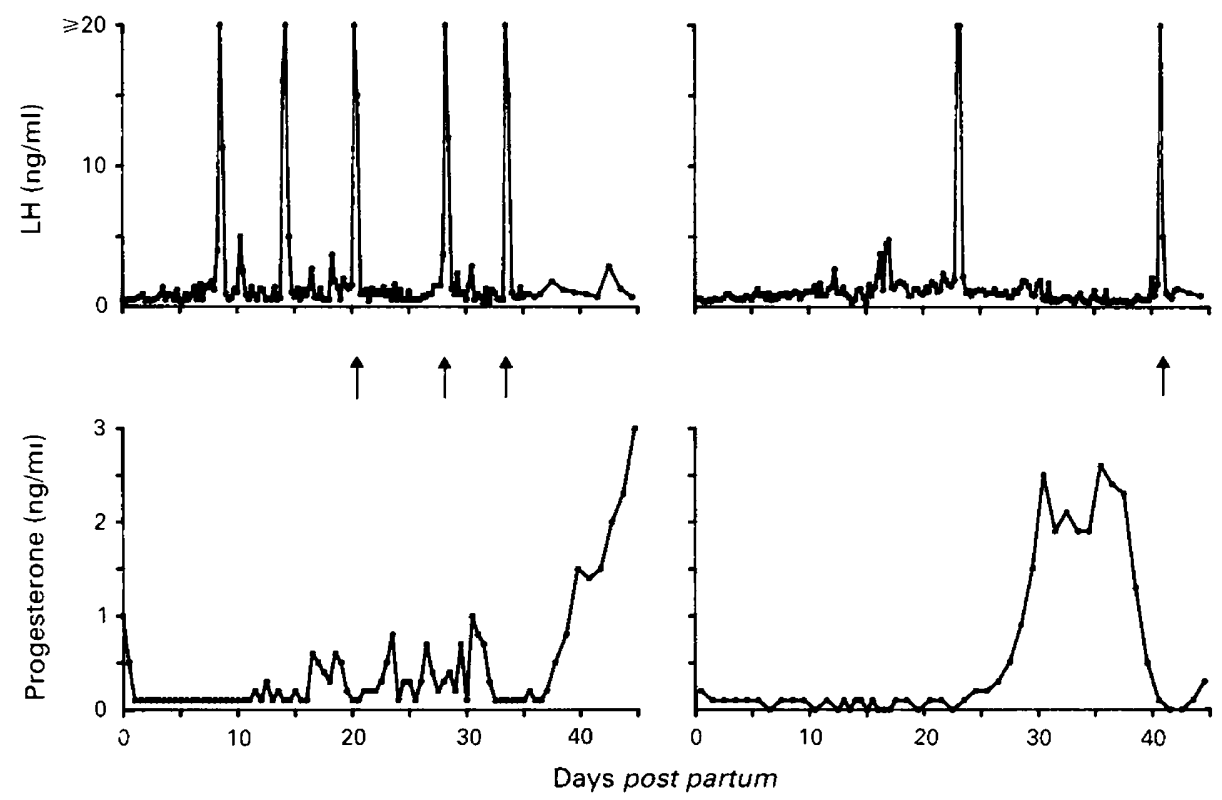

Fig. 2. Changes in plasma LH and progesterone concentrations in 1 ewe in Group NS (left) and 1 ewe in Group $\mathrm{S}$ (right). Arrows indicate days of oestrus.

\section{Discussion}

In well-fed Préalpes du Sud ewes lambing in the autumn the interval between parturition and first oestrus was very variable, ranging from 9 to $>55$ days. Non-suckling ewes displayed oestrus at an average of 22 days post partum, namely 13 days earlier than ewes that nursed one or several lambs. 
This result is in agreement with the well-known delaying effect of lactation on the return of oestrus after lambing (Mauléon \& Dauzier, 1965; Hunter, 1968). It indicates that the length of anoestrus is not related to the number of lambs nursed and, therefore, that duration of anoestrus is not proportional to the number of suckling stimuli or the level of milk production (Schirar, 1986). This conclusion corroborates those of other workers who have shown that length of post-partum anoestrus was not different in ewes suckling 1 or 2 lambs (Barker \& Wiggins, 1964) or even 3 lambs (Land, 1971), and in ewes suckling their lambs freely or 4 times a day (Cognié et al., 1982).

It has been well established that oestrus expression in the ewe requires the sequential action of progesterone and oestradiol (Robinson, 1954; Signoret, 1970). Nearly all suckling ewes (28/29 displayed first oestrus at the completion of a normal or abnormal period of progesterone secretion while more than half of the non-suckling ewes $(12 / 22)$ were found in oestrus before any change in progesterone concentrations was detected in daily blood samples. In fact, in some of these ewes, measurement of progesterone concentrations in the blood samples collected every $6 \mathrm{~h}$ before exhibition of oestrous behaviour showed small and short-lasting variations accounting for luteal activity, undoubtedly deficient but most probably high enough to induce oestrous activity.

Return of oestrous behaviour after an autumn lambing cannot be considered as the criterion of re-establishment of a regular cyclic activity because recurrence of oestrus does not necessarily signify that a normal oestrous cycle will follow. In this regard, the observation of a higher incidence of abnormal luteal phases in ewes returning to oestrus or resuming ovulation early is of interest. This result is consistent with those of Menge et al. (1962) and Hinshelwood et al. (1982), who showed a greater incidence of short cycles among cows displaying oestrus before Day 20 and with those of Carter et al. (1980) who found a positive correlation between interval to oestrus and oestrous cycle length in beef cows. It is also in agreement with those of Wallace et al. (1989) who reported that ewes induced to ovulate showed a greater incidence of inadequate luteal phases on Day 21 than on Day 35 post partum.

This incidence of abnormal luteal phases noted in the present work and by Wallace et al. (1989) indicates that inadequate luteal function is specific to the peculiar physiological situation of the ewes early after lambing. Schirar et al. (1989) have suggested that it might result from the luteolytic influence of the involuting uterus and an incomplete restoration of LH release leading to insufficient follicle growth and maturation (R. J. Scaramuzzi \& Y. Cognié, unpublished data). However, in the present work as well as in other studies in naturally ovulating ewes (Sharpe et al., 1986; Schirar et al., 1989) and cows (Hinshelwood et al., 1982) a higher incidence of abnormal luteal phases was observed in non-suckling than in suckling ewes. This finding, and the small delay (6 days) in the resumption of normal oestrous cycle, suggests that suckling, rather than delaying the return of potential fertility, primarily affects the conditions of this return by acting as a protective or a regulatory mechanism to ensure an harmonious post-partum resumption of ovarian activity. Quirke et al. (1983) found in lactating ewes that the first-service conception rate was $82 \%$ at about 52 days post partum, while Tchamitchian et al. (1973) observed that in non-lactating ewes exhibiting oestrus at about 24 days post partum most of the conceptions took place around Day 40 post partum. Finally, in naturally ovulating ewes, the reappearance of oestrus heralds the re-establishment of reproductive ability in suckling ewes, but does not have the same significance in nonsuckling females.

\section{References}

Barker, H.B. \& Wiggins, E.L. (1964) Estrual activity in lactating ewes. J. Anim. Sci. 23, 973-980.

Carter, M.L., Dierschke, D.J., Rutledge, J.J. \& Hauser, E.R. (1980) Effect of gonadotropin-releasing hormone and calf removal on pituitary-ovarian function and reproductive performance in postpartum beef cows. J. Anim. Sci. 51, 903-910.
Cognié, Y., Gayerie, F., Poulin, N. \& Saumande, J. (1982) Ovarian-pituitary dialogue during the postpartum period in the ewe. Curr. Top. Vet. Med. Anim. Sci. 20, 305-313.

Hammond, J. (1961) Fertility. In Marshall's Physiology of Reproduction, 3rd edn, vol. II, ch. 21 , p. 656 . Ed. A. S. Parkes. Longmans, London. 
Hinshelwood, M.M., Hansen, P.J. \& Hauser, E.R. (1982) Short oestrous cycles in postpartum cows as influenced by level of milk production, suckling, diet, season of calving and interval to first estrus. Theriogenology 18, 383-392.

Hunter, G.L. (1968) Increasing the frequency of pregnancy in sheep. Anim. Breed. Abstr. 36, 347-378; 533-553.

Land, R.B. (1971) The incidence of oestrus during lactation in Finnish-Landrace, Dorset Horn and Finn Dorset sheep. J. Reprod. Fert. 24, 345-352.

Lees, J.L. (1964) Inhibitory effect of lactation on the breeding activity of the ewe. Nature, Lond. 203, 1089-1090.

Mauléon, P. \& Dauzier, L. (1965) Variations de la durée de l'anoestrus de lactation chez les brebis de race Ile de France. Annls Biol. anim. Biochim. Biophys. 5, $131-141$.

Menge, A.C., Mares, S.E., Tyler, W.J. \& Casida, L.E. (1962) Variation and association among postpartum reproduction and production characteristics in Holstein-Friesian cattle. J. Dairy Sci. 45, 233-241.

Palmer, E. \& Jousset, D. (1975) Urinary oestrogen and plasma progesterone levels in non pregnant mares. $J$. Reprod. Fert., Suppl. 23, 213-221.

Pelletier, J., Kann, G., Dolais, J. \& Rosselin, G. (1968) Dosage radio-immunologique de l'hormone lutéinisante plasmatique chez le mouton. Mise au point de la technique de dosage. C. r. hebd. Séanc. Acad. Sci., Paris D 266, 2291-2294.

Quirke, J.F., Stabenfeldt, G.H. \& Bradford, G.E. (1983) Resumption of ovarian function in autumn lambing Dorset, Rambouillet and Finnish Landrace ewes. Theriogenology 19, 243-248.

Robinson, T.J. (1954) Relationship of oestrogen and progesterone in oestrous behaviour in the ewe. Nature, Lond. 173, 878

Robinson, T.J. (1965) use of progestagen-impregnated sponges inserted intra-vaginally or sub-cutaneously for the control of the oestrous cycle in the sheep. Nature, Lond. 206, 3941.

SAS Institute Inc. (1987) SAS/STAT Guide for Personal Computers, Version 6 edition. SAS Institute Inc., Cary.

Schirar, A, (1986) L'anoestrus de lactation chez la brebis Préalpes du Sud. Reprise de l'activité gonadotrope hypothalamo-hypophysaire et de l'activité ovarienne. Thèse de Doctorat d'Etat es Sciences Naturelles, 84 pp. Université Paris VI, Paris.

Schirar, A., Meusnier, C., Paly, J., Levasseur, M.C. \& Martinet, J. (1989) Resumption of ovarian activity in post-partum ewes: role of the uterus. Anim. Reprod. Sci. 19, 79-89.

Sharpe, P.H., McKibbin, P.E., Murphy, B.D. \& Manns, J.G. (1986) First postpartum ovulations and corpora lutea in ewes which lamb in the breeding season. Anim. Reprod. Sci. 10, 61-74.

Signoret, J.P. (1970) Action d'implants de benzoate d'oestradiol dans l'hypothalamus sur le comportement d'oestrus de la brebis ovariectomisée. Annls Biol. anim. Biochim. Biophys. 10, 549-566.

Tchamitchian, L., Ricordeau, G., Lefèvre, C. \& Desvignes, A. (1973) Observations sur l'anoestrus post partum des brebis Romanov après un agnelage en saison sexuelie. Annls Zootech. 22, 295-301.

Thimonier, J., Mauléon, P., Cognié, Y. \& Ortavant, R. (1968) Déclenchement de l'oestrus et obtention de la gestation pendant l'anoestrus post partum chez la brebis à l'aide d'éponges vaginales imprégnées d'acétate de fluorogestone. Annls Zootech. 17, 257-273.

Wallace, J.M., Robinson, J.J. \& Aitken, R.P. (1989) Does inadequate luteal function limit the establishment of pregnancy in the early post-partum ewe? $J$. Reprod. Fert. 85, 229-240. 